\title{
Pliocene three-dimensional global ocean temperature reconstruction
}

\author{
H. J. Dowsett, M. M. Robinson, and K. M. Foley \\ United States Geological Survey, MS 926A, 12201 Sunrise Valley Drive, Reston, VA 20192, USA
}

Received: 8 June 2009 - Published in Clim. Past Discuss.: 15 July 2009

Revised: 12 November 2009 - Accepted: 15 November 2009 - Published: 3 December 2009

\begin{abstract}
The thermal structure of the mid-Piacenzian ocean is obtained by combining the Pliocene Research, Interpretation and Synoptic Mapping Project (PRISM3) multiproxy sea-surface temperature (SST) reconstruction with bottom water temperature estimates from 27 locations produced using $\mathrm{Mg} / \mathrm{Ca}$ paleothermometry based upon the ostracod genus Krithe. Deep water temperature estimates are skewed toward the Atlantic Basin (63\% of the locations) and represent depths from $1000 \mathrm{~m}$ to $4500 \mathrm{~m}$. This reconstruction, meant to serve as a validation data set as well as an initialization for coupled numerical climate models, assumes a Pliocene water mass framework similar to that which exists today, with several important modifications. The area of formation of present day North Atlantic Deep Water (NADW) was expanded and extended further north toward the Arctic Ocean during the mid-Piacenzian relative to today. This, combined with a deeper Greenland-Scotland Ridge, allowed a greater volume of warmer NADW to enter the Atlantic Ocean. In the Southern Ocean, the Polar Front Zone was expanded relative to present day, but shifted closer to the Antarctic continent. This, combined with at least seasonal reduction in sea ice extent, resulted in decreased Antarctic Bottom Water $(\mathrm{AABW})$ production (relative to present day) as well as possible changes in the depth of intermediate waters. The reconstructed mid-Piacenzian three-dimensional ocean was warmer overall than today, and the hypothesized aerial extent of water masses appears to fit the limited stable isotopic data available for this time period.
\end{abstract}

\section{Introduction}

Future warming projected by the Intergovernmental Panel on Climate Change (IPCC) (Jansen et al., 2007) poses large socioeconomic impacts to the world community (Robinson et al., 2008a). Thus, the ability to plan for future climate change is a national if not a global priority. Researching, interpreting

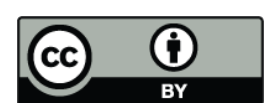

Correspondence to: H. J. Dowsett (hdowsett@usgs.gov) and modeling past warm climate states refines climate models used to project future climate scenarios and facilitates our ability to confidently model future change. At present, however, most fully coupled ocean-atmosphere paleoclimate modeling experiments utilize a modern or homogenous ocean temperature dataset for initialization due to the lack of available data on past conditions. A three-dimensional ocean temperature reconstruction of a past warmer-than-present climate state is needed to initialize the models to better approximate a warmer global scenario and to shorten start-up time, thus making model runs more cost effective.

The USGS Pliocene Research, Interpretation and Synoptic Mapping (PRISM) Project develops data sets that describe the major elements of the climate system during the midPiacenzian, a time recognized by many as a possible, albeit imperfect, analog to future conditions (Dowsett, 2007; Robinson et al., 2008a,b; Salzmann et al., 2008; Dowsett and Robinson, 2009; Dowsett et al., 2009; Sohl et al., 2009). The mid-Piacenzian is particularly relevant to future climate change since it is the most recent period of Earth history that exhibited global mean annual temperatures equivalent to those projected for the end of this century (Jansen et al., 2007).

The PRISM paleoclimate reconstruction contains all major boundary conditions including reconstructions of land ice distribution, sea ice distribution, vegetation, sea surface temperature (SST), sea level and topography and is the most comprehensive and internally consistent reconstruction of any period of Earth history older than the last interglacial. PRISM data are provided to the paleoclimate modeling community through a series of digital data sets as part of the PRISM Data-Model Cooperative, also known as the Pliocene Model Intercomparison Project (PlioMIP) (see Chandler et al., 2008; Robinson et al., 2008a). These data are being used in a number of climate model experiments to help understand the magnitude and cause of Pliocene climate change relative to the present (see Chandler et al., 2008).

Through the addition of key sites, the PRISM SST reconstruction has been updated and refined to better approximate Pliocene climate, particularly in the equatorial Pacific and the

Published by Copernicus Publications on behalf of the European Geosciences Union. 


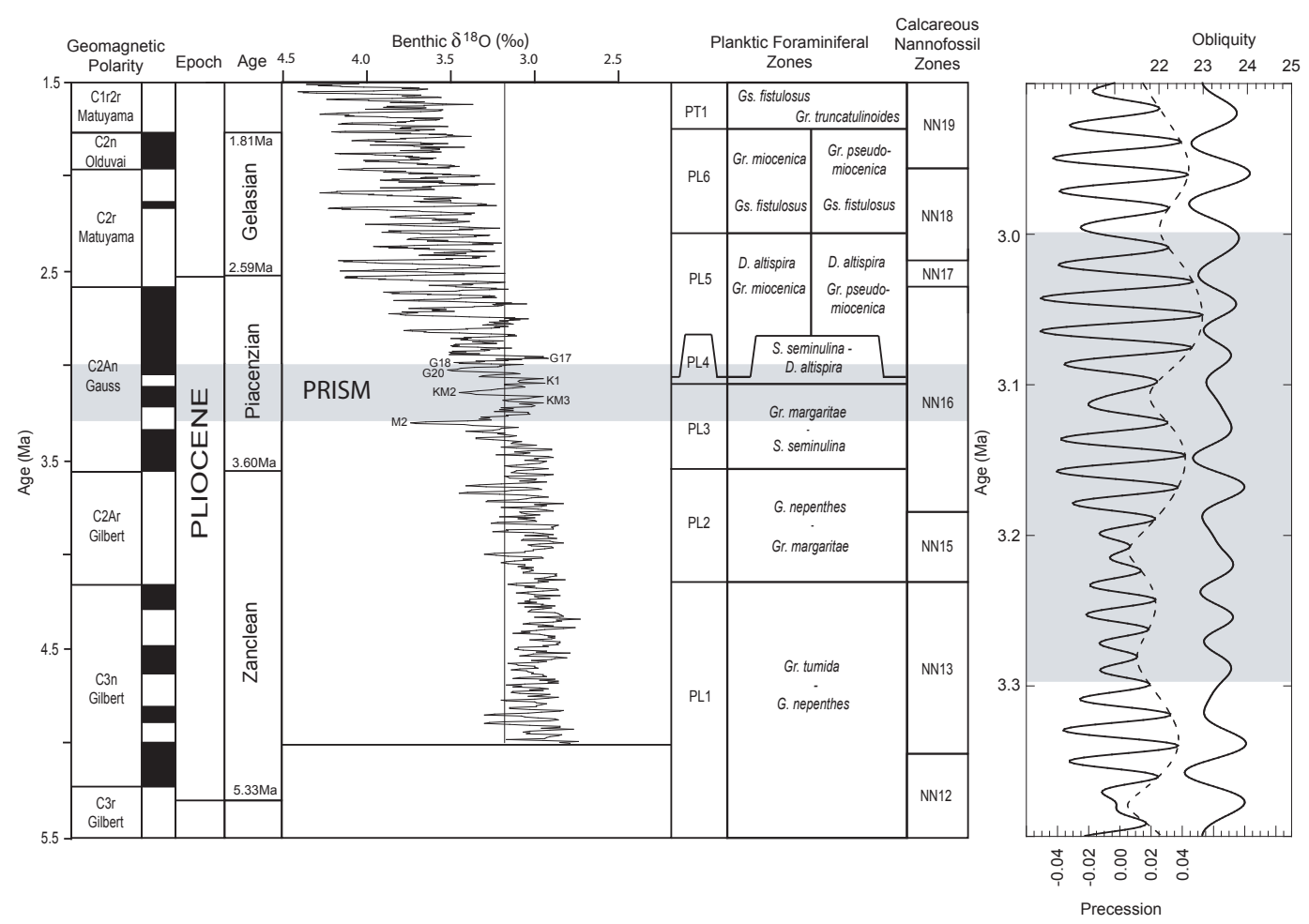

Fig. 1. Pliocene magnetobiostratigraphic framework after Berggren et al. (1995). Gray band approximates the PRISM time slab. Benthic $\delta^{18} \mathrm{O}$ record from Lisiecki and Raymo (2005). Position of PRISM time slab (shaded horizontal band) relative to geomagnetic polarity, planktic foraminiferal zones, calcareous nannofossil zones and orbital geometry (Berggren 1973, 1977; Berggren et al., 1995; Martini, 1971). Note low-amplitude obliquity cycles throughout the mid-Piacenzian with precessional cycles that build in amplitude from the earlier to later part of the PRISM time slab. Eccentricity is shown by dashed line tracing upper limit of precession (Dowsett et al., 2005). Epoch column represents recent potential changes to the placement of the Pliocene-Pleistocene boundary at the bottom rather than top of the Gelasian. Figure modified from Dowsett et al. (2005) and Dowsett and Robinson (2006).

northeastern Atlantic Oceans. Also, using new bottom water temperature data, PRISM has developed a three-dimensional global ocean temperature reconstruction that is consistent with both existing data on Pliocene ocean circulation and also the new PRISM SST reconstruction. Here we present one possible (non-unique) reconstruction of global ocean temperature designed to initiate coupled ocean-atmosphere general circulation models of earth climate and an interpretation of mid-Piacenzian water mass behavior.

\section{Mid-Piacenzian warmth and the PRISM time interval}

The middle part of the Piacenzian age of the Pliocene epoch was a period of relatively warm yet variable climate when continental positions were basically the same as at present and much of the extant Pliocene flora and fauna were shifted to higher latitudes suggestive of a global warming (Dowsett, 2007). Warming during this time period, relative to present conditions, increased with increasing latitude. Estimates of atmospheric $\mathrm{CO}_{2}$ concentrations, however, show values only slightly higher than pre-industrial concentrations (Raymo et al., 1996), suggesting that mid-Piacenzian warmth was not driven soley by increases in greenhouse gases, the proposed culprit for current and future warming (Jansen et al., 2007). Instead mid-Piacenzian warmth may have been a response to enhanced meridional oceanic heat transport (Dowsett et al., 1992; Brierley et al., 2009), a change in sill depth allowing enhanced production of Northern Component Water or NCW (Wright and Miller, 1996; Poore et al., 2006), larger and or more frequent tropical storm events (Emanuel, 2001), or some combination of these mechanisms. Many resources are being focused on understanding the causes of mid-Piacenzian global warmth in an attempt to better understand future climate conditions.

The PRISM interval, calibrated to $3.29 \mathrm{Ma}$ to $2.97 \mathrm{Ma}$ (timescale of Gradstein et al., 2004) (Fig. 1), is defined not only by absolute age but also in terms of position relative to biostratigraphic, magnetostratigraphic and stable isotopic zonations. It is a $\sim 300 \mathrm{Ky}$ interval of time within the middle part of the Piacenzian Age of the Pliocene Epoch. In the literature, this interval is frequently referred to as mid-Piacenzian, PRISM "Time Slab" or PRISM Interval. All refer to the interval between the transition of marine 
Table 1. PRISM3 SST Estimates.

\begin{tabular}{|c|c|c|c|c|c|c|c|c|c|c|c|}
\hline \# & Locality & Lat & Lon & $\begin{array}{c}\text { Water } \\
\text { Depth (m) }\end{array}$ & $\begin{array}{c}\text { Modern }^{\mathrm{a}} \\
\text { February SST }\end{array}$ & $\begin{array}{c}\text { Modern }^{\mathrm{a}} \\
\text { August SST }\end{array}$ & $\begin{array}{c}\text { Modern }{ }^{\mathrm{b}} \text { Mean } \\
\text { Annual SST }\end{array}$ & $\begin{array}{c}\text { PRISM3 }{ }^{\mathrm{c}} \\
\text { February SST }\end{array}$ & $\begin{array}{c}\text { PRISM3 }^{\mathrm{d}} \\
\text { Multiproxy SST }\end{array}$ & $\begin{array}{c}\text { PRISM3 }^{\mathrm{d}} \\
\text { August SST }\end{array}$ & $\begin{array}{c}\text { Selected } \\
\text { Publications }\end{array}$ \\
\hline 1 & DSDP 310 & 36.87 & -176.90 & 3516.0 & 14.06 & 24.15 & 17.28 & 17.06 & - & 26.15 & {$[\mathrm{f}]$} \\
\hline 2 & ODP 886 & 44.69 & -168.24 & 5713.7 & 7.27 & 14.85 & 10.48 & 4.67 & - & 17.95 & {$[\mathrm{~g}]$} \\
\hline 3 & DSDP 183 & 54.58 & -161.21 & 4708.0 & 2.88 & 11.31 & 7.48 & 1.68 & - & 13.61 & {$[\mathrm{~g}]$} \\
\hline 4 & E14-8 & -59.67 & -160.29 & 3877.0 & 3.70 & 1.22 & 1.91 & $>4.60$ & - & - & {$[\mathrm{g}]$} \\
\hline 5 & Colvillian & 70.29 & -150.42 & 0.0 & -1.79 & -1.78 & 2.09 & 0.21 & - & 2.22 & [f] \\
\hline 6 & ODP 887 & 54.37 & -148.45 & 3633.6 & 4.08 & 12.25 & 8.47 & 6.08 & - & 13.25 & {$[\mathrm{f}]$} \\
\hline 7 & DSDP 573 & 0.49 & -133.30 & 4301.0 & 25.62 & 24.90 & 25.90 & 24.62 & 24.70 & 24.70 & {$[\mathrm{~h}]$} \\
\hline 8 & DSDP 36 & 40.98 & -130.12 & 3273.0 & 11.71 & 17.88 & 14.99 & 13.71 & - & 19.88 & [f] \\
\hline 9 & ODP 1021 & 39.09 & -127.78 & 4213.0 & 11.64 & 16.99 & 14.50 & - & 21.50 & - & {$[\mathrm{h}]$} \\
\hline 10 & E13-17 & -65.68 & -124.11 & 4724.0 & 1.10 & -1.49 & -0.03 & $<5.50$ & - & - & {$[\mathrm{g}]$} \\
\hline 11 & ODP 1014 & 32.83 & -119.98 & 1165.7 & 14.32 & 18.27 & 16.10 & - & 24.00 & - & [h] \\
\hline 12 & ODP 852 & 5.28 & -110.07 & 3860.1 & 27.09 & 26.74 & 27.00 & - & 29.40 & - & {$[\mathrm{h}]$} \\
\hline 13 & Meighen Island & 79.00 & -99.00 & 0.0 & -1.79 & -1.79 & -0.55 & 0.21 & - & 3.21 & {$[\mathrm{f}]$} \\
\hline 14 & DSDP 323 & -63.68 & -97.99 & 5004.0 & 3.19 & 0.44 & 1.85 & $>4.39$ & - & - & [f] \\
\hline 15 & ODP 847 & 0.18 & -95.32 & 3334.5 & 26.06 & 22.10 & 24.40 & 28.45 & 26.90 & 25.72 & {$[\mathrm{~h}]$} \\
\hline 16 & ODP 677 & 1.20 & -83.74 & 3472.5 & 26.27 & 25.58 & 25.60 & 28.91 & 27.50 & 26.67 & [h] \\
\hline 17 & Sarasota & 27.25 & -82.66 & 0.0 & 20.48 & 29.36 & 25.36 & 19.88 & - & 26.96 & [f] \\
\hline 18 & Pinecrest Beds & 27.35 & -82.43 & 0.0 & 20.48 & 29.36 & 24.36 & 20.48 & - & 29.36 & [f] \\
\hline 19 & Cayo Aqua & 9.15 & -82.05 & 0.0 & 27.99 & 28.38 & 27.59 & 27.99 & - & 29.50 & {$[\mathrm{f}]$} \\
\hline 20 & SEFlor(G-182) & 25.78 & -80.28 & 0.0 & 23.34 & 29.57 & 26.25 & 21.34 & - & 30.00 & {$[\mathrm{f}]$} \\
\hline 21 & DSDP 502 & 11.49 & -79.38 & 3051.0 & 26.65 & 28.10 & 27.69 & 27.80 & - & 27.57 & [i] \\
\hline 22 & Duplin & 34.00 & -79.00 & 0.0 & 20.41 & 28.57 & 23.54 & 19.71 & - & 28.17 & [f] \\
\hline 23 & Lee Creek & 35.38 & -76.75 & 0.0 & 14.46 & 27.03 & 21.10 & 16.76 & - & 30.13 & [f] \\
\hline 24 & Yorktown & 37.00 & -76.50 & 0.0 & 10.11 & 25.93 & 19.89 & 15.31 & - & 27.73 & [f] \\
\hline 25 & ODP 1237 & -16.00 & -76.37 & 3212.3 & 23.06 & 16.39 & 20.00 & 28.37 & 23.20 & 21.90 & [h] \\
\hline 26 & DSDP 603 & 35.49 & -70.03 & 4633.0 & 19.94 & 27.08 & 22.57 & 25.24 & 23.70 & 27.53 & [i] \\
\hline 27 & DSDP 541 & 15.52 & -58.72 & 4940.0 & 25.97 & 28.11 & 27.11 & 27.84 & 21.73 & 27.56 & [i] \\
\hline 28 & ODP 672 & 15.50 & -58.50 & 4982.5 & 25.97 & 28.11 & 27.11 & 27.57 & 21.73 & 26.88 & [i] \\
\hline 29 & ODP 646 & 58.25 & -48.33 & 3440.3 & 2.15 & 7.37 & 5.41 & 3.62 & - & 9.54 & [f] \\
\hline 30 & DSDP 396 & 22.90 & -43.50 & 4459.0 & 23.46 & 26.39 & 24.88 & 24.75 & - & 27.53 & [f] \\
\hline 31 & ODP 695 & -62.39 & -43.45 & 1300.1 & 0.05 & -1.79 & 0.00 & $<4.72$ & - & - & {$[\mathrm{f}]$} \\
\hline 32 & DSDP 606 & 37.34 & -35.50 & 3007.0 & 16.50 & 24.37 & 20.50 & 18.30 & 21.90 & 25.50 & [j] \\
\hline 33 & DSDP 516 & -30.27 & -35.28 & 1313.0 & 23.98 & 18.48 & 22.25 & 26.00 & - & 20.50 & [f] \\
\hline 34 & DSDP 607 & 41.00 & -32.96 & 3427.0 & 15.34 & 22.86 & 18.80 & 16.20 & 19.80 & 23.30 & [j] \\
\hline 35 & ODP 699 & -51.54 & -30.68 & 3705.5 & 3.83 & 1.00 & 3.63 & 5.80 & - & - & {$[\mathrm{g}]$} \\
\hline 36 & DSDP 410 & 45.51 & -29.48 & 2976.0 & 13.34 & 19.21 & 15.86 & 16.10 & - & 25.00 & [f] \\
\hline 37 & DSDP 609 & 49.88 & -24.24 & 3883.5 & 11.48 & 16.55 & 14.10 & 14.60 & 18.70 & 22.80 & [j] \\
\hline 38 & DSDP 552 & 56.04 & -23.23 & 2301.0 & 9.07 & 13.33 & 11.60 & 12.80 & 16.70 & 21.00 & [j] \\
\hline 39 & DSDP 608 & 42.84 & -23.09 & 3526.0 & 13.68 & 20.70 & 17.11 & 17.76 & - & 25.60 & {$[\mathrm{~g}]$} \\
\hline 40 & ODP 667 & 4.55 & -21.90 & 3524.9 & 27.34 & 26.81 & 27.50 & 27.28 & - & 26.79 & [i] \\
\hline 41 & ODP 659 & 18.08 & -21.03 & 3071.7 & 20.94 & 24.47 & 22.42 & 22.26 & - & 27.66 & [i] \\
\hline 42 & DSDP 366 & 5.68 & -19.85 & 2853.0 & 27.32 & 26.81 & 27.47 & 27.84 & - & 27.20 & {$[\mathrm{~g}]$} \\
\hline
\end{tabular}

oxygen isotope stages M2/M1 and G19/G18 (Shackleton et al., 1995) in the middle part of the Gauss Normal Polarity Chron (C2An), ranging from within C2An2r (Mammoth reversed polarity) to near the bottom of C2An1 (just above Kaena reversed polarity). This interval correlates in part to planktic foraminiferal zones PL3 (Globorotalia margaritae-Sphaeroidinellopsis seminulina Interval Zone), PL4 (Sphaeroidinellopsis seminulina-Dentoglobigerina altispira Interval Zone) and PL5 (Dentoglobigerina altispiraGloborotalia miocenica Interval Zone) of Berggren et al. (1995). It falls within calcareous nannofossil zone NN16 of Martini (1971) or CN12a of Bukry $(1973,1975)$ (Dowsett and Robinson, 2006).

The PRISM interval occurs prior to the first strong oxygenisotope excursions, which represent a change toward modern conditions (Northern Hemisphere ice volume increased, polar fronts were strengthened and glacial-interglacial variation intensified) (Sancetta and Silvestri, 1986; Raymo et al., 1989; Hodell and Ciesielski, 1991; Dowsett et al., 1994). While the PRISM interval is easily distinguished from the intervals immediately surrounding it, there is a high degree of variability within the time slab. The $41 \mathrm{ky}$ period of Earth's obliquity dominates the Pliocene climate record (Tiedemann et al., 1994). Other than glacial stages KM2 (c. 3.12 Ma) and G20 (c. $3.01 \mathrm{Ma}$ ), benthic foraminiferal oxygen isotope values were either equal to or isotopically lighter than those of today (Shackleton et al., 1995; Lisiecki and Raymo, 2005) (Fig. 1). 
Table 1. Continued.

\begin{tabular}{|c|c|c|c|c|c|c|c|c|c|c|c|}
\hline \# & Locality & Lat & Lon & $\begin{array}{c}\text { Water } \\
\text { Depth (m) }\end{array}$ & $\begin{array}{c}\text { Modern }^{\mathrm{a}} \\
\text { February SST }\end{array}$ & $\begin{array}{c}\text { Modern }^{\mathrm{a}} \\
\text { August SST }\end{array}$ & $\begin{array}{l}\text { Modern }{ }^{\mathrm{b}} \text { Mean } \\
\text { Annual SST }\end{array}$ & $\begin{array}{c}\text { PRISM }^{\mathrm{c}} \\
\text { February SST }\end{array}$ & $\begin{array}{c}\text { PRISM3 }^{\mathrm{d}} \\
\text { Multiproxy SST }\end{array}$ & $\begin{array}{c}\text { PRISM3 }^{\mathrm{d}} \\
\text { August SST }\end{array}$ & $\begin{array}{c}\text { Selected } \\
\text { Publications }\end{array}$ \\
\hline 43 & ODP 661 & 9.45 & -19.39 & 4012.9 & 24.81 & 26.91 & 26.49 & 27.12 & - & 26.72 & [i] \\
\hline 44 & DSDP 610 & 53.22 & -18.89 & 2426.3 & 10.49 & 14.98 & 13.15 & 14.16 & - & 24.33 & [i] \\
\hline 45 & Tjornes & 66.16 & -17.25 & 0.0 & 1.35 & 7.38 & 4.39 & 5.35 & - & 13.58 & [f] \\
\hline 46 & ODP 693 & -70.83 & -14.57 & 2359.0 & -0.92 & -1.79 & -0.48 & $<4.28$ & - & - & [g] \\
\hline 47 & DSDP 548 & 48.85 & -12.00 & 1251.0 & 11.34 & 17.18 & 14.14 & 18.31 & - & 27.62 & [i] \\
\hline 48 & DSDP 521 & -26.07 & -10.27 & 4127.5 & 24.74 & 19.45 & 22.89 & 26.74 & - & 21.45 & {$[\mathrm{f}]$} \\
\hline 49 & DSDP 546 & 33.80 & -9.60 & 3958.0 & 16.73 & 22.33 & 18.95 & 19.11 & - & 24.17 & [i] \\
\hline 50 & ODP 690 & -65.16 & 1.21 & 2914.0 & 0.90 & -1.79 & 0.00 & $<5.80$ & - & - & [g] \\
\hline 51 & North Sea & 52.50 & 1.50 & 0.0 & 5.71 & 16.34 & 10.97 & 10.41 & - & 16.74 & {$[\mathrm{f}]$} \\
\hline 52 & ODP 909 & 78.58 & 3.07 & 2518.6 & -1.80 & -0.74 & 0.79 & - & 13.20 & & {$[\mathrm{k}]$} \\
\hline 53 & ODP 704 & -46.88 & 7.42 & 2532.3 & 7.07 & 4.81 & 6.72 & 9.57 & - & 7.31 & [f] \\
\hline 54 & PS1448 & -58.64 & 7.92 & 4970.0 & 1.06 & -1.75 & -0.18 & $<4.03$ & - & - & [f] \\
\hline 55 & ODP 911 & 80.47 & 8.23 & 901.5 & -1.79 & -1.67 & -0.03 & - & 18.10 & & {$[\mathrm{k}]$} \\
\hline 56 & DSDP 532 & -19.74 & 10.52 & 1331.0 & 20.88 & 15.79 & 18.82 & 22.68 & - & 17.59 & [f] \\
\hline 57 & DSDP 132 & 40.25 & 11.43 & 2835.0 & 13.78 & 25.04 & 18.74 & 15.38 & - & 26.64 & [g] \\
\hline 58 & ODP 907 & 69.25 & -12.70 & 1801.2 & 5.85 & 10.91 & 3.23 & - & 11.70 & & {$[\mathrm{k}]$} \\
\hline 59 & Punta di Maiata & 37.33 & 13.50 & 0.0 & 14.62 & 25.75 & 19.61 & 17.50 & - & 21.27 & [g] \\
\hline 60 & Punta Piccola & 37.33 & 13.58 & 0.0 & 14.62 & 25.75 & 19.61 & 18.84 & - & 23.88 & {$[\mathrm{~g}]$} \\
\hline 61 & Finikia & 35.25 & 25.17 & 0.0 & 15.41 & 24.31 & 20.43 & 16.14 & - & 19.90 & {$[\mathrm{~g}]$} \\
\hline 62 & ODP 722 & 16.62 & 59.80 & 2022.1 & 25.00 & 24.77 & 26.84 & 26.05 & - & 27.04 & {$[\mathrm{~g}]$} \\
\hline 63 & ODP 736 & -49.40 & 71.66 & 628.7 & 4.48 & 1.77 & 3.74 & $<7.48$ & - & - & [f] \\
\hline 64 & ODP 747 & -54.81 & 76.79 & 1695.8 & 2.41 & 0.14 & 1.90 & $>4.51$ & - & - & [f] \\
\hline 65 & ODP 748 & -58.44 & 78.98 & 1289.6 & 1.44 & -1.70 & 1.15 & $<4.64$ & - & - & {$[\mathrm{f}]$} \\
\hline 66 & ODP 751 & -57.73 & 79.81 & 1633.8 & 1.69 & -1.33 & 1.21 & $<4.59$ & - & - & {$[\mathrm{f}]$} \\
\hline 67 & ODP 745 & -59.60 & 85.86 & 4082.5 & 1.84 & -1.55 & 1.06 & $<4.74$ & - & - & [f] \\
\hline 68 & DSDP 266 & -56.40 & 110.11 & 4167.0 & 3.48 & 0.66 & 1.82 & $>4.68$ & - & - & [f] \\
\hline 69 & ODP 769 & 8.78 & 121.29 & 3644.0 & 26.89 & 28.73 & 28.70 & 26.89 & 28.10 & 29.23 & {$[\mathrm{~h}]$} \\
\hline 70 & DSDP 445 & 25.52 & 133.20 & 3377.0 & 20.98 & 28.46 & 25.60 & 22.98 & 26.30 & 29.46 & {$[\mathrm{~h}]$} \\
\hline 71 & Yabuta & 37.00 & 137.00 & 0.0 & 9.86 & 24.95 & 17.81 & 9.86 & - & 24.95 & [f] \\
\hline 72 & Sasaoka & 39.50 & 140.50 & 0.0 & 7.01 & 22.12 & 16.62 & 8.51 & - & 24.12 & {$[\mathrm{f}]$} \\
\hline 73 & E50-28 & -62.90 & 150.68 & 3489.0 & 1.87 & -1.69 & 0.98 & $<4.97$ & - & - & [f] \\
\hline 74 & E36-33 & -57.75 & 150.88 & 3952.0 & 3.67 & 0.84 & 3.21 & $>4.67$ & - & - & [g] \\
\hline 75 & DSDP 579 & 38.63 & 153.84 & 5737.0 & 12.03 & 23.33 & 17.27 & 17.53 & - & 27.73 & [f] \\
\hline 76 & DSDP 580 & 41.63 & 153.98 & 5375.0 & 6.19 & 19.79 & 13.43 & 12.39 & - & 23.09 & [f] \\
\hline 77 & DSDP 586 & -0.50 & 158.50 & 2207.0 & 29.26 & 29.01 & 29.20 & 29.26 & 29.20 & 29.01 & {$[\mathrm{~h}]$} \\
\hline 78 & ODP 806 & 0.31 & 159.36 & 2520.5 & 29.16 & 29.00 & 29.20 & 28.96 & 29.60 & 28.32 & {$[\mathrm{~h}]$} \\
\hline 79 & ODP 881 & 47.10 & 161.49 & 5530.9 & 2.44 & 12.11 & 6.78 & 4.34 & - & 15.91 & {$[\mathrm{f}]$} \\
\hline 80 & E. Kamchatka & 56.00 & 163.00 & 0.0 & 0.11 & 11.35 & 7.45 & 4.11 & - & 10.85 & [f] \\
\hline 81 & Karaginsky & 58.85 & 164.04 & 0.0 & -0.94 & 11.26 & 6.41 & 3.06 & - & 13.26 & [f] \\
\hline 82 & DSDP 592 & -36.47 & 165.44 & 1088.0 & 20.33 & 15.11 & 18.28 & 22.33 & - & 17.11 & {$[\mathrm{~g}]$} \\
\hline 83 & ODP 883 & 51.20 & 167.77 & 2390.8 & 2.71 & 10.38 & 6.45 & 3.20 & - & 14.90 & [f] \\
\hline 84 & E50-33 & -61.09 & 170.06 & 4550.0 & 4.00 & 0.24 & 3.02 & $>4.50$ & - & - & [g] \\
\hline 85 & DSDP 274 & -68.99 & 173.43 & 3305.0 & -0.48 & -1.79 & -0.40 & $<4.52$ & - & - & [g] \\
\hline 86 & Rangitikei R. & -39.50 & 175.87 & 0.0 & 17.97 & 13.23 & 16.12 & 19.97 & - & 15.23 & [g] \\
\hline
\end{tabular}

${ }^{\mathrm{a}}$ Reynolds and Smith (1995), ${ }^{\mathrm{b}}$ Levitus and Boyer (1994), ${ }^{\mathrm{c}}$ Faunal based SST estimate, ${ }^{\mathrm{d}} \mathrm{SST}$ estimate based upon multiple proxies: Mg/Ca, alkenone and faunal methods, ${ }^{\mathrm{e}}$ Reference for more information on site, ${ }^{\mathrm{f}}$ Dowsett et al. (1996), ${ }^{\mathrm{g}}$ Dowsett et al. (1999), ${ }^{\mathrm{h}}$ Dowsett and Robinson (2009), ${ }^{\mathrm{i}}$ Dowsett and Robinson (2006), ${ }^{\mathrm{j}}$ Robinson et al. (2008b), ${ }^{\mathrm{k}}$ Robinson (2009)

\section{Sea surface temperature estimates}

New multiple proxy SST estimates are now available for the sub-polar North Atlantic and Arctic Oceans (Robinson, 2009) and for the low latitude Pacific Ocean (Dowsett and Robinson, 2009) that greatly enhance and extend the PRISM SST reconstruction into regions previously not represented. The resulting PRISM3 SST Reconstruction now utilizes 86 localities (Fig. 2, Table 1).

Most PRISM SST estimates are based on microfossil species assemblages. SST estimates are derived from these faunal data using a warm peak averaging methodology to ex- tract the warm phase of climate from the PRISM interval at each location (see Dowsett and Robinson, 2006; Dowsett, 2007). Warm peak averaging, pioneered by Dowsett and Poore (1990), attempts to determine the average peak warming during the PRISM interval. Only estimates meeting some pre-set quality control criteria are used (Dowsett, 2007). A warm peak is defined as a temperature warmer than the estimates surrounding it in a stratigraphic sequence. Thus, all warm peaks are defined, those not meeting quality control are excluded, and the remainders are averaged. 


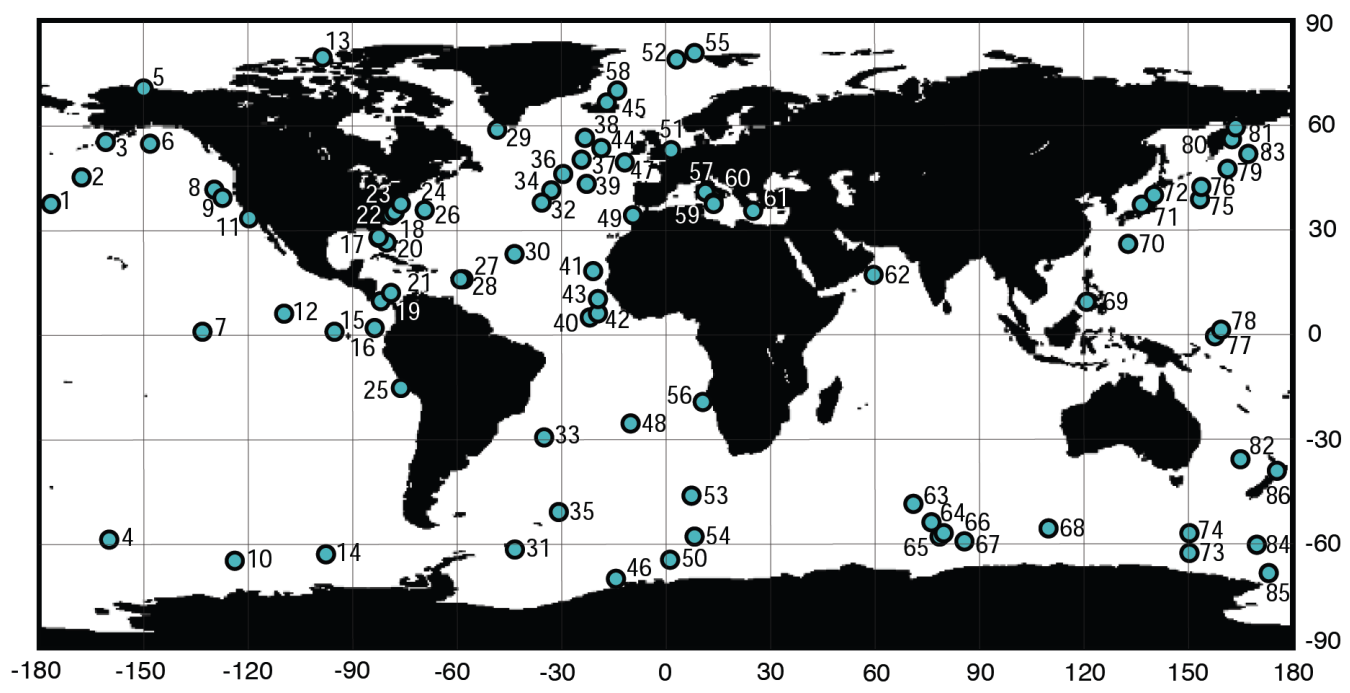

Fig. 2. Location of sites used for surface temperature reconstruction.

$\mathrm{Mg} / \mathrm{Ca}$ and alkenone paleotemperature proxies are utilized as supplemental data where faunal data are already available. In these situations, careful analysis of multiple independent proxies are used to verify each other and gain further insight into the structure of the upper water column (e.g. Robinson et al., 2008b; Dowsett and Robinson, 2009). In areas where faunal proxies are missing or do not work, $\mathrm{Mg} / \mathrm{Ca}$ and alkenone methods are used alone to estimate SST.

While one SST proxy is not intrinsically better than another, we do not feel multiple proxies should necessarily show concordance. The power of a multiple proxy approach is that no two proxies actually measure the same environmental variable in the same way. The power of the technique lies with this diversity. In practical terms, having faunal based SST estimates for winter and summer bracket a mean annual SST alkenone-based estimate, and a $\mathrm{Mg} / \mathrm{Ca}$ estimate from a signal carrier that lives at depth being slightly cooler than the alkenone-based estimate calibrated to $10 \mathrm{~m}$, gives a much more complete and robust estimate of paleoenvironmental conditions. Looking for statistical agreement between multiple proxies is an oversimplification of the problem and in many cases invalid.

\section{Bottom water temperature estimates}

Data from 27 DSDP and ODP sites, representing conditions ranging from $\sim 1000 \mathrm{~m}$ to $\sim 4500 \mathrm{~m}$ water depth, are used in our bottom water temperature analysis (Fig. 3, Table 2; Cronin et al., 2005; Dwyer, 2009; Dwyer and Chandler, 2009). The Atlantic sector has by far the best threedimensional coverage. Sites in the Pacific Ocean and Indian Ocean sectors are primarily from the Southern Hemisphere. $\mathrm{The} \mathrm{Mg} / \mathrm{Ca}$ ratio of shells of the deep-sea ostracode genus Krithe is used to infer bottom water temperature (BWT) dur- ing the mid-Piacenzian. Ostracodes are bivalved Crustacea whose shells are made of calcite $\left(\mathrm{Ca} \mathrm{CO}_{3}\right)$ containing minor amounts of coprecipitated magnesium. Using coretop Krithe from the North Atlantic collected over $2^{\circ}$ to $14^{\circ} \mathrm{C}$, Dwyer et al. (1995) determined a calibration for Krithe such that BWT $\left({ }^{\circ} \mathrm{C}\right)=(0.854 \times \mathrm{Mg} / \mathrm{Ca})-5.75$, with an error of $+/-1^{\circ} \mathrm{C}$. BWT estimates that fall below $2^{\circ} \mathrm{C}$ are assumed valid assuming that the relationship between $\mathrm{Mg} / \mathrm{Ca}$ and temperature remains linear below $2^{\circ} \mathrm{C}$.

Dwyer et al. (1995) found that postmortem alteration of the shell, i.e. dissolution, had little effect on the $\mathrm{Mg} / \mathrm{Ca}$ ratio in Krithe shells and concluded that dissolution does not alter the original composition of deep-sea Krithe shells to the point where it might obscure the bottom water temperature signature. In addition, the authors found no substantial interspecific variation in the $\mathrm{Mg} / \mathrm{Ca}$ ratio.

Utilizing ostracods for $\mathrm{Mg} / \mathrm{Ca}$ paleothermometry has some advantages over benthic foram applications. Ontogenetic problems can be minimized by using a particular molt stage, valves do not lend themselves to contamination due to trapped sediment in chambers, and ostracod valves have relatively high concentrations of minor elements ( $\sim 4$ to 40 times greater than the commonly-used species of benthic or planktonic foraminifers), thus further decreasing any possible impact of contamination (Cronin et al., 2005).

However, a carbonate ion effect has been documented for benthic foraminifera at temperatures below approximately $4^{\circ} \mathrm{C}$ (Yu and Elderfield, 2007; Raitzsch et al., 2008). At present insufficient data exists for the ostracods to determine the significance of this effect, which could impact BWT estimates of Cronin et al. (2005) and Dwyer (2009), used in our reconstruction. 
Table 2. Deep Ocean Temperature Estimates.

\begin{tabular}{cccccccc}
\hline Locality & Lat & Lon & $\begin{array}{c}\text { Water } \\
\text { Depth }(\mathrm{m})\end{array}$ & $\begin{array}{c}\text { Max 10\% } \\
\text { Anomaly }\end{array}$ & $\begin{array}{c}\text { Max 10\% } \\
\text { Temperature }\end{array}$ & $\begin{array}{c}\text { Water } \\
\text { Mass }^{\mathrm{b}}\end{array}$ & $\begin{array}{c}\text { Selected } \\
\text { Publications }\end{array}$ \\
\hline IODP 1123 & -41.79 & -171.50 & 3290.1 & 1.2 & 2.7 & CPDW & {$[\mathrm{d}]$} \\
IODP 1241 & 5.84 & -86.44 & 2027.3 & 0.2 & 2.5 & PCW & {$[\mathrm{d}]$} \\
IODP 1239 & -0.67 & -82.08 & 1414.7 & 0.3 & 3.6 & PCW & {$[\mathrm{d}]$} \\
IODP 1236 & -21.36 & -81.44 & 1323.7 & -1.9 & 1.4 & AAIW/PCW & {$[\mathrm{d}]$} \\
DSDP 502 & 11.49 & -79.38 & 3051.0 & -0.9 & 3.2 & AIW & {$[\mathrm{e}]$} \\
IODP 1237 & -16.01 & -76.38 & 3212.7 & 0.9 & 2.5 & PCW/CPDW & {$[\mathrm{d}]$} \\
ODP 928 & 5.46 & -43.75 & 4011.0 & 1.2 & 3.4 & NADW & {$[\mathrm{d}]$} \\
ODP 929 & 5.98 & -43.74 & 4356.0 & 0.3 & 2.5 & NADW/AABW & {$[\mathrm{d}]$} \\
ODP 925 & 4.20 & -43.49 & 3041.0 & 2.0 & 4.7 & NADW & {$[\mathrm{f}]$} \\
ODP 926 & 3.72 & -42.91 & 3598.0 & 2.0 & 4.5 & NADW & {$[\mathrm{f}]$} \\
DSDP 607 & 41.00 & -32.96 & 3427.0 & 1.5 & 4.0 & NADW & {$[\mathrm{e}, \mathrm{f}]$} \\
DSDP 552 & 56.04 & -23.23 & 2301.0 & 3.2 & 6.3 & UNADW & {$[\mathrm{e}]$} \\
ODP 659 & 18.08 & -21.03 & 3072.0 & -0.5 & 2.3 & NADW & {$[\mathrm{e}]$} \\
ODP 661 & 9.45 & -19.39 & 4013.0 & 0.3 & 2.7 & NADW & {$[\mathrm{e}]$} \\
DSDP 610 & 53.22 & -18.89 & 2417.0 & 0.2 & 3.3 & NADW & {$[\mathrm{e}]$} \\
ODP 658 & 20.75 & -18.58 & 2263.0 & 1.7 & 4.9 & NADW & {$[\mathrm{e}]$} \\
ODP 982 & 57.52 & -15.87 & 1134.0 & -1.0 & 4.6 & UNADW & {$[\mathrm{d}]$} \\
ODP 959 & 3.63 & -2.74 & 2091.0 & 0.6 & 4.1 & AAIW/NADW & {$[\mathrm{d}]$} \\
IODP 1092 & -46.41 & 7.08 & 1973.0 & -0.6 & 1.7 & CPDW/NADW & {$[\mathrm{d}]$} \\
ODP 704 & -46.88 & 7.42 & 2532.0 & 4.2 & 6.1 & NADW & {$[\mathrm{e}]$} \\
IODP1090 & -42.91 & 9.00 & 3700.0 & 0.4 & 2.0 & NADW/CPDW & {$[\mathrm{d}]$} \\
IODP 1085 & -29.37 & 13.99 & 1713.0 & 0.3 & 3.3 & CPDW & {$[\mathrm{d}]$} \\
ODP 754 & -30.94 & 93.57 & 1063.6 & -0.3 & 4.8 & SURF/AAIW & {$[\mathrm{d}]$} \\
ODP 806 & 0.32 & 159.36 & 2520.7 & 0.9 & 2.8 & PDW & {$[\mathrm{d}]$} \\
ODP 805 & 1.23 & 160.53 & 3188.5 & 0.5 & 2.3 & PDW & {$[\mathrm{d}]$} \\
ODP 804 & 0.94 & 161.65 & 3861.7 & 0.3 & 1.9 & PDW & {$[\mathrm{d}]$} \\
DSDP 592 & -36.47 & 165.44 & 1088.0 & -2.1 & 3.3 & SURF/AAIW & {$[\mathrm{d}]$} \\
\hline
\end{tabular}

${ }^{\mathrm{a}}$ Temperature and anomaly (Pliocene minus modern) based upon warmest $10 \%$ of data, ${ }^{\mathrm{b}}$ Water mass sampled by site during present day: CPDW=CircumPolar Deep Water, PCW=Pacific Central Water, AAIW=Antarctic Intermediate Water, AIW=Atlantic Intermediate Water, NADW=North Atlantic Deep Water, AABW=Antarctic Bottom Water, PDW=Pacific Deep Water, ${ }^{\mathrm{c}}$ Reference for more information on site, ${ }^{\mathrm{d}}$ Dwyer (2009), ${ }^{\mathrm{e}}$ Cronin et al. (2005), ${ }^{\mathrm{f}}$ Dwyer and Chandler (2009)

Further discussion of the ostracod based $\mathrm{Mg} / \mathrm{Ca}$ paleothermometry technique and results are described elsewhere (Cronin et al., 2005; Dwyer and Chandler, 2009). For the remainder of this paper, these $\mathrm{Mg} / \mathrm{Ca}$ data are collectively referred to as the deep ocean temperature data set.

We used a methodology similar to that used for PRISM SST data to extract the warm phase of bottom water temperature from the deep ocean temperature data set. Deep ocean temperature data at each site were ranked, and the highest $10 \%$ were averaged to produce the estimates shown in Figs. 3 and 4 and Table 2. The limited numbers of samples from some deep ocean temperature sites precluded warm peak averaging. Where time series were of sufficient length, a comparison of estimates generated from both techniques showed the deep ocean temperature estimates to fall, as expected, be- tween those that would be obtained using warm peak averaging and the maximum temperature technique of Dowsett et al. (2005).

\section{PRISM 3-D ocean reconstruction}

Several assumptions are necessary to define the framework of the PRISM 3-D reconstruction. First, we assume the same general pattern of large-scale ocean circulation seen in the modern ocean because we find no evidence in the data that would suggest, for example, deep-water formation in the North Pacific during the PRISM interval. Next, we assume an increased flux of warm surface water to the high latitude North Atlantic and adjacent seas during the PRISM interval, 


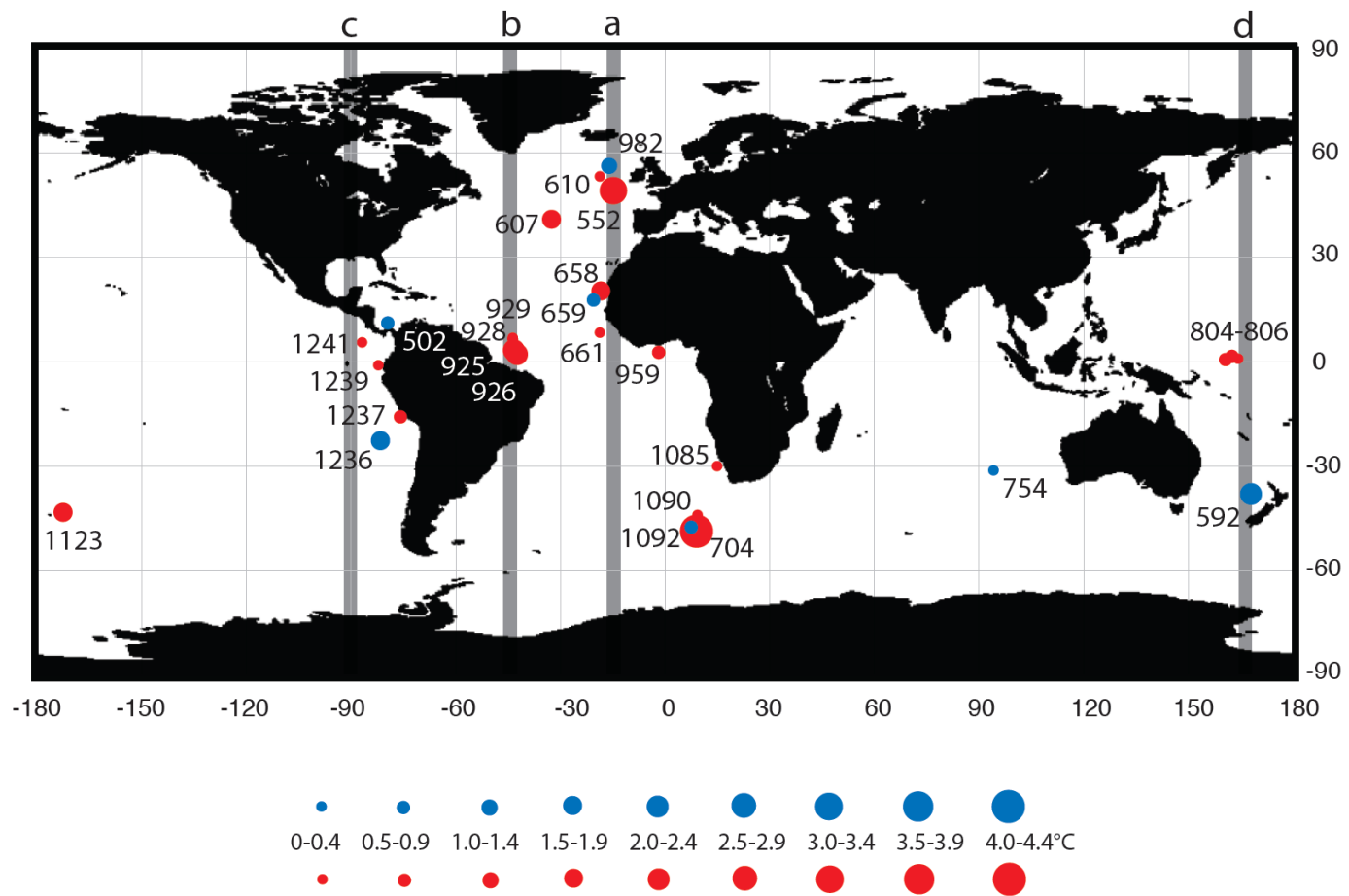

Fig. 3. Location of sites utilized in deep ocean temperature analysis. Size of dots indicate magnitude of temperature anomaly (Pliocene minus present day); blue=cooler than modern, red=warmer than modern. Lines a-d show position of longitudinal transects given in Fig. 8 .

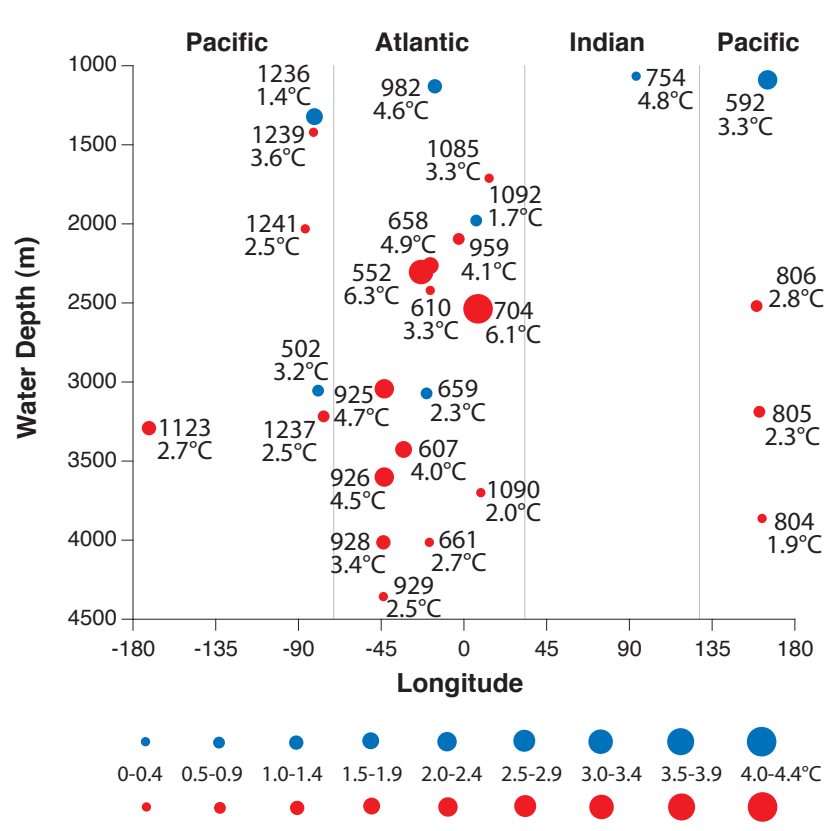

Fig. 4. Maximum (top 10\%) mid-Piacenzian deep ocean temperature estimates by water depth from all sites, projected onto an equatorial plane. Symbols are in Fig. 3. suggested by surface temperature estimates from multiple locations (Dowsett et al., 2009) (Fig. 5) and robust results of $\delta^{13} \mathrm{C}$ analyses from records intersecting the PRISM interval arguing for a high flux of paleo North Atlantic Deep Water (NADW) (Wright and Miller, 1996; Poore et al., 2006).

Finally, we assume that the warm phase of the deep ocean temperature data is most likely coupled with the warm peak averaged PRISM SST reconstruction. PRISM's goal is a reconstruction of a "super interglacial", not mean conditions. This is a significant assumption since high frequency temperature variability can be observed in many of the deep ocean records (Dwyer and Chandler, 2009) and since the ability to correlate millennial scale features from core to core across the globe does not yet exist at a sufficient number of sites (Dowsett and Robinson, 2006).

These assumptions taken together suggest a conceptual model of increased mid-Piacenzian meridional overturning circulation (MOC) relative to present day, forcing an adjustment in the extent of NADW, Antarctic Bottom Water (AABW) and Antarctic Intermediate Water (AAIW). 
February (PRISM3 - Modern)

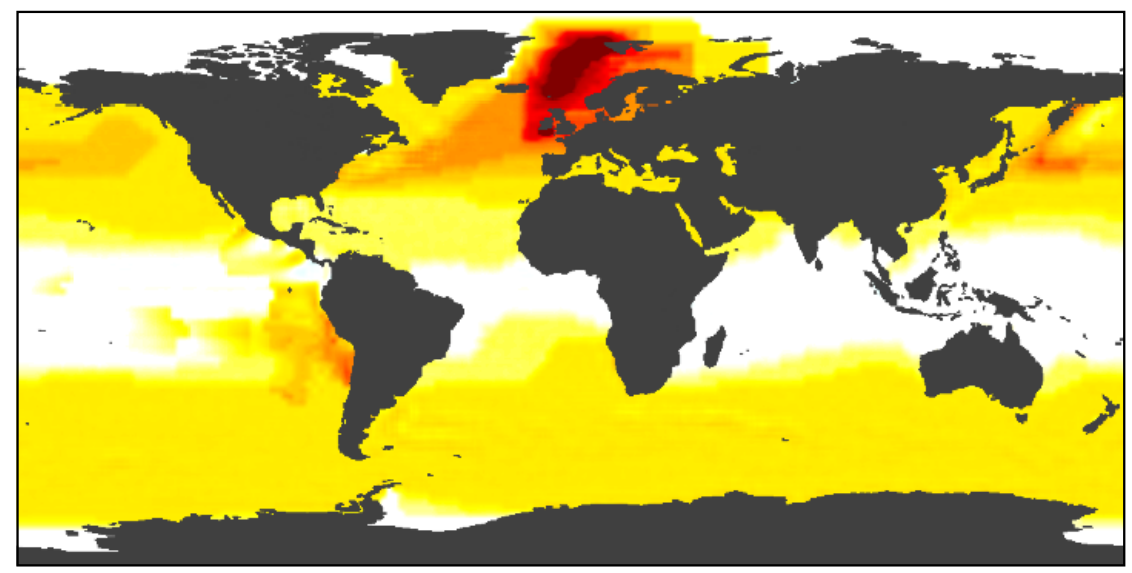

August (PRISM3 - Modern)
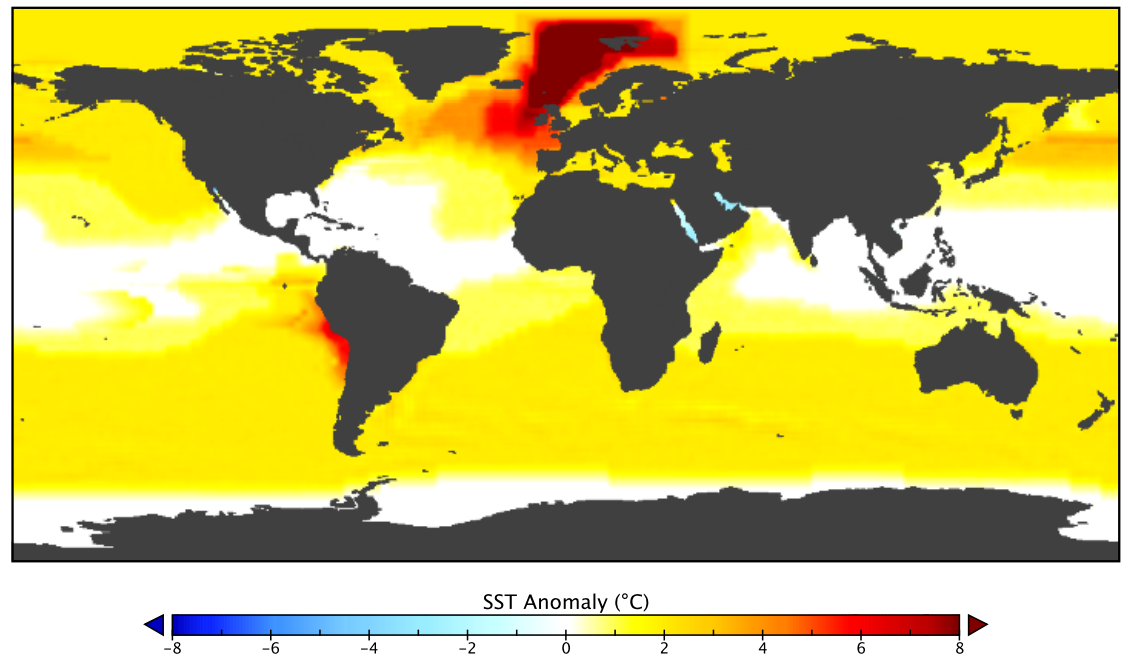

Fig. 5. February (a) and August (b) mid-Piacenzian surface temperature anomalies.

\subsection{Sea surface temperature reconstruction}

Surface temperature estimates presented here comprise the PRISM3 SST data set (Dowsett et al., 1999; Dowsett, 2007; Robinson et al., 2008b; Dowsett and Robinson, 2009; Robinson, 2009), based upon 86 DSDP and ODP sites (Fig. 2, Table 1). Contouring the global SST field from so few irregularly spaced data points is a problematic task. Early attempts at automated contouring of the raw data, using algorithms from Middleton (2000), resulted in unrealistic oceanographic solutions (not shown). In order to facilitate model - model comparisons, PRISM elected to have researchers most familiar with the data and its strengths and weaknesses produce subjectively contoured datasets using the methodology outlined below. Much of the design of these datasets (e.g. monthly SST and sea ice) clearly goes beyond the resolution of the raw data, but was required by the modeling community.
At each locality, modern SST was subtracted from the PRISM time-slab value in order to produce a mid-Piacenzian SST anomaly for cold and warm seasons. To create a global dataset, these SST anomalies were plotted as individual points on a $2^{\circ} \times 2^{\circ}$ grid representing the Earth. Modern SST contours served as a rough guide to draw anomaly contours around the control points, because it was assumed that the general pattern of modern oceanic surface current systems was present in the mid-Piacenzian. Boundaries between anomaly bands were smoothed to create even temperature gradients. Finally, this smoothed, contoured anomaly field (Fig. 5) was added to the modern SST of Reynolds and Smith (1995) to create mid-Piacenzian February and August SST maps (Fig. 6). SSTs for the remaining 10 months of the year were derived by fitting a sine curve to the February and August SST estimates (Dowsett et al., 1996). 
PRISM3 SST: February

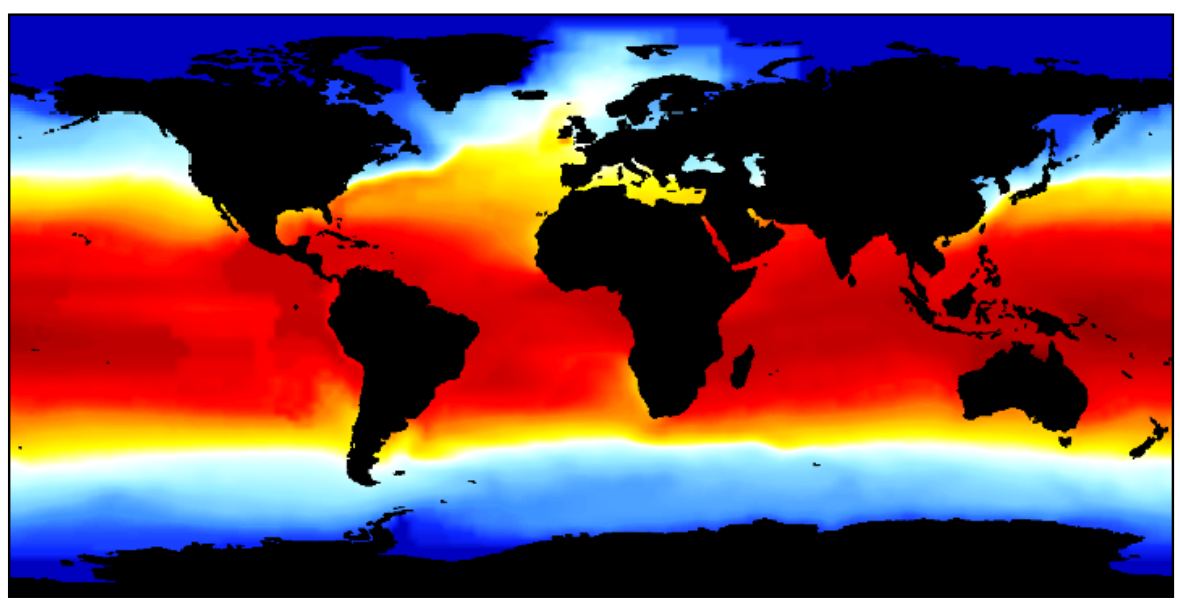

PRISM3 SST: August

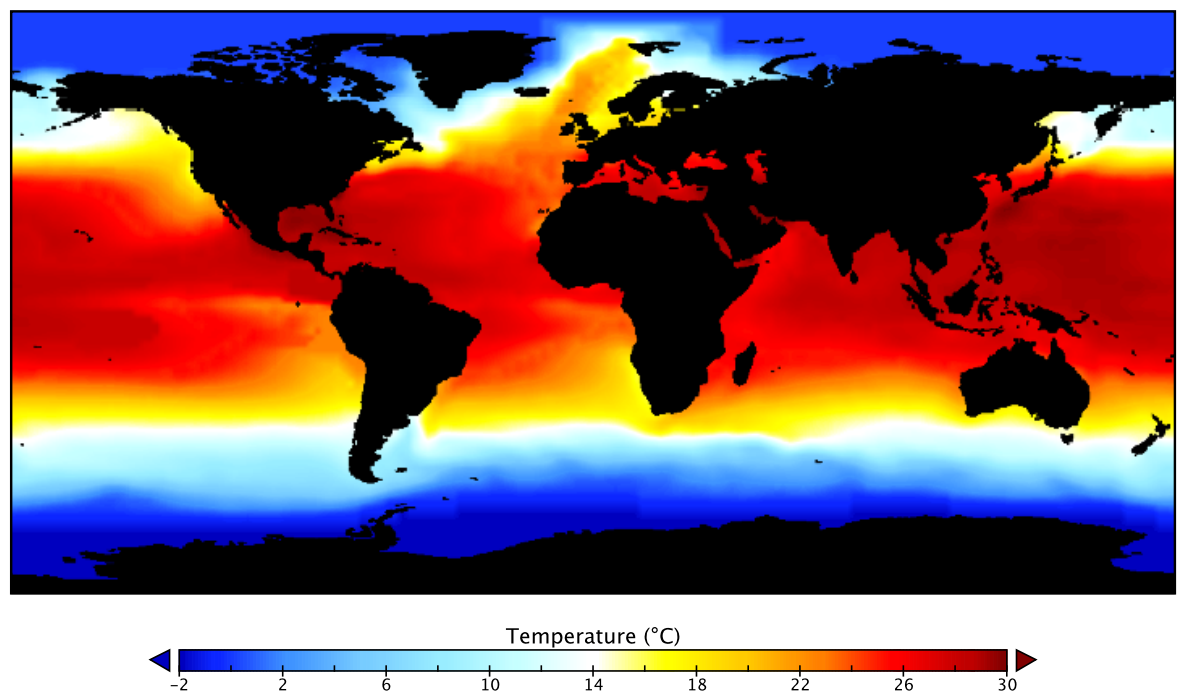

Fig. 6. February (a) and August (b) mid-Piacenzian SST maps.

\subsection{3-D ocean temperature reconstruction}

The PRISM 3-D ocean reconstruction is presented at a $4^{\circ}$ latitude by $5^{\circ}$ longitude resolution at 33 depth layers. Specific steps in the reconstruction methodology are listed in Supplement A (http://www.clim-past.net/5/769/ 2009/cp-5-769-2009-supplement.pdf).

Because the PRISM 3-D reconstruction is designed for coupled ocean-atmosphere general circulation models, it represents a reconstruction of a prescribed day, arbitrarily chosen to be 1 December. The Levitus and Boyer (1994) modern ocean temperature dataset was transformed into a $4^{\circ} \times 5^{\circ}$ resolution. The PRISM3 November and December monthly SST reconstructions were averaged to approximate the SST for mid-Piacenzian 1 December. A surface-temperature anomaly was created by subtracting the modern 1 December
SST field (Reynolds and Smith, 1995) from the Piacenzian 1 December data (Fig. 7). The surface temperature anomaly was then added to the $0 \mathrm{~m}$ layer of Levitus and Boyer (1994) to create the PRISM 3-D $0 \mathrm{~m}$ reconstruction (Fig. 8).

Our deep ocean temperature reconstruction is based upon 27 localities, unevenly distributed among the ocean basins. In addition, the number of samples at each locality varies depending upon the availability of specimens. While not optimum for generating a global reconstruction, this represents possibly the largest number of temperature estimates for any deep water reconstruction from any time interval.

Since no data points fall between $0 \mathrm{~m}$ and $1100 \mathrm{~m}$ in the deep ocean temperature data set, we chose to use a mathematical function that decreases the weight of the surface anomaly with depth down to $1400 \mathrm{~m}$ (see Dowsett et al., 2006). Between $900 \mathrm{~m}$ and $1400 \mathrm{~m}$ that anomaly was further modified based upon data from Sites 592, 754, 1092 


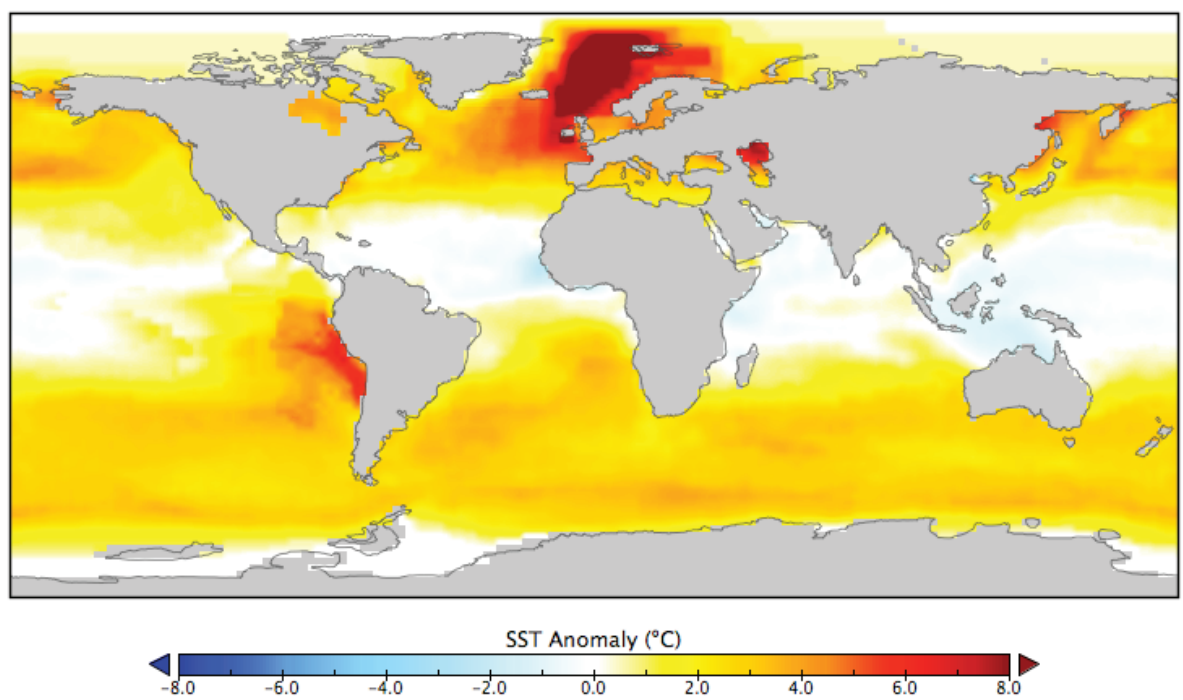

Fig. 7. Pliocene estimated 1 December surface temperature anomaly based upon PRISM3 SST reconstruction.

and 1236 that we feel represent an adjustment or vertical expansion of paleo AAIW (Fig. 4). Therefore, we restrict cooler temperatures in the Southern Hemisphere to this depth interval.

In the Atlantic sector of the Southern Ocean, the data at Sites 1085, 1090, 1092 and 704 may indicate warmer paleo NADW that expands further into the region (Fig. 8a) relative to modern day. At present, Site 704 sits in the core of NADW; during the mid-Piacenzian Site 704 shows a strong warm anomaly (Figs. 3 and 4). Slight cooling near the upper boundary of NADW and Circum Polar Deep Water (CPDW) (Site 1092) with slight warming at the lower boundary (Site 1090) would be expected with an expansion of paleo NADW.

The production of warmer paleo NADW during the midPiacenzian is evident from the anomalies at Sites 552, 610 and 607 (Figs. 3 and 4). At all three sites, the expansion or increased production of paleo NADW at the expense of AABW is seen as a warm anomaly (Fig. 8a and b). This fits well with the documented warming of the sea surface in the region of NADW production and the proposed expansion of paleo NADW production to higher latitudes in the Arctic Ocean. It is plausible that a vertical expansion of $p a-$ leo NADW could cause the slight negative anomaly seen at Site 982 , currently bathed by Upper NADW.

In the equatorial Atlantic today, Sites 925, 926, 928 and 929 monitor NADW and, at the deepest point (Site 929, $4356 \mathrm{~m}$ ), the boundary between NADW and AABW. Warm anomalies for the mid-Piacenzian at all sites are in keeping with the hypothesized warmer and stronger flux of $p a-$ leo NADW and diminished (colder) paleo AABW production relative to today (Figs. 3, 4, and 8b).
Sites 658, 659 and 661 all monitor NADW today, and the warm anomalies at 658 and 661 record the regional mid-Piacenzian warmth shown at most other locations. The slight negative anomaly at Site 659 ( $\sim 3000 \mathrm{~m}$ water depth) does not fit our conceptual model. Because the deep ocean temperature data contain only three samples from this site (Dwyer, 2009) we do not place high confidence in these temperature estimates.

In the western Pacific, Sites 804, 805, 806 and 1123 monitor Pacific Deep Water (PDW) today, and all show small positive anomalies for the mid-Piacenzian. We interpret these data to indicate the overall warmer conditions of the water masses that mixed to form paleo PDW (Fig. 8d).

In the eastern Pacific, Sites 1236, 1239, 1241 and 1237 form a depth transect from the present day boundary of AAIW and Pacific Central Water (PCW) (1236), through PCW (1239 and 1241) to the boundary between PCW and CPDW (1237) (Figs. 3, 4, and 8c). In keeping with our hypothetical distribution of mid-Piacenzian water masses, a vertical displacement of AAIW could explain the minor cooling at the top of this transect while overall warming of PCW is in keeping with the positive anomalies at the three lower sites along the depth transect.

\section{Discussion}

Temperature is not a tracer for water mass. Our reconstruction assumes a modern water mass framework and imposes changes to those water masses based upon the deep ocean temperature data, published literature and our knowledge of mid-Piacenzian sea-surface circulation and temperature. We make reference to modern water masses but are actually referring to the temperature signals of their paleo analogs. 


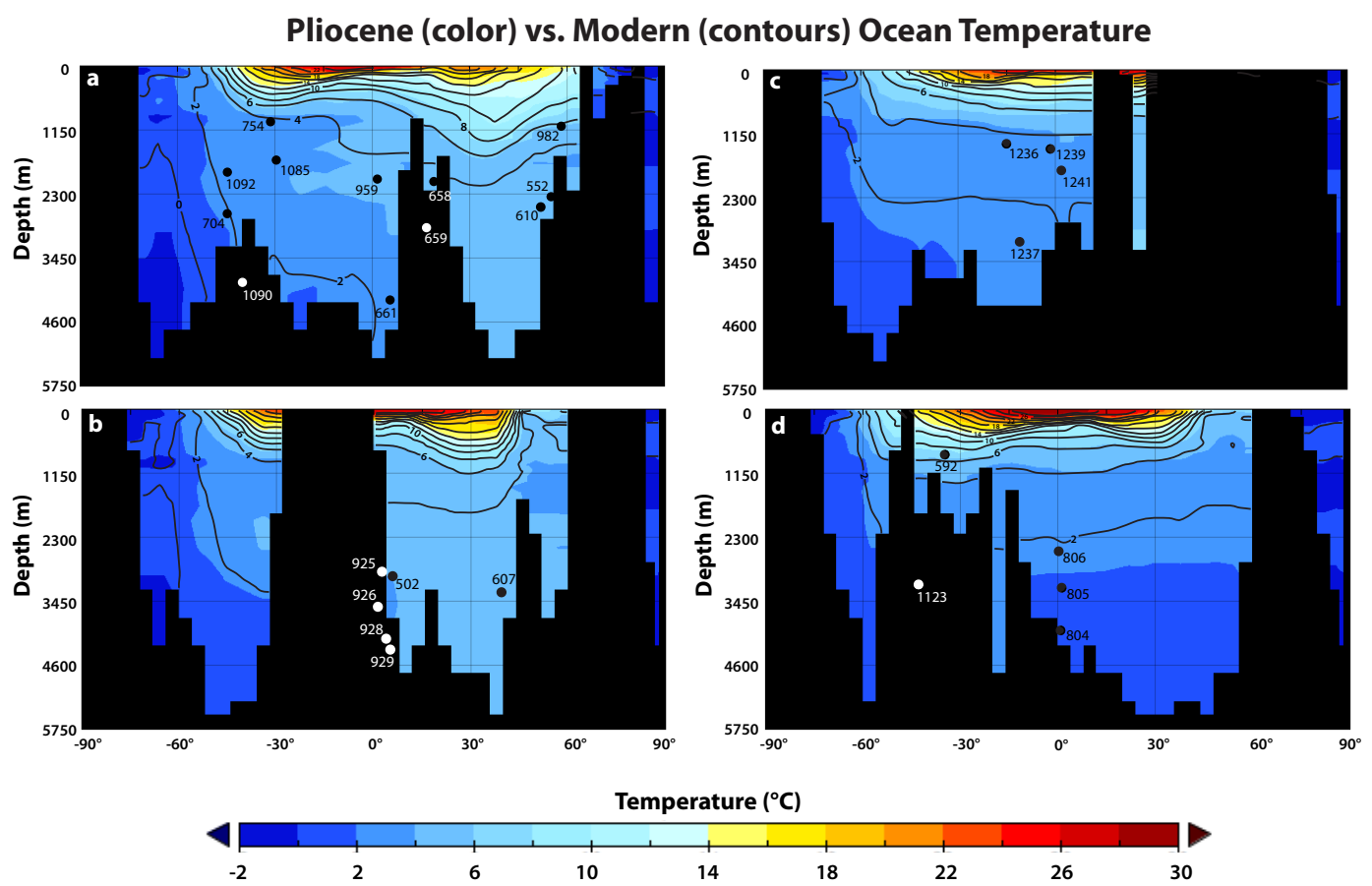

Fig. 8. Longitudinal profiles of ocean temperature from transects shown in Fig. 3: (a) $15^{\circ} \mathrm{W}$, (b) $45^{\circ} \mathrm{W}$, (c) $90^{\circ} \mathrm{W}$ and (d) $165^{\circ} \mathrm{E}$. All temperatures are shown in ${ }^{\circ} \mathrm{C}$. Contour interval is $2^{\circ} \mathrm{C}$. Black contour lines show modern temperature overlaid on colored regions showing the mid-Piacenzian reconstruction. The change in temperature can be surmised by comparing the color contours to the black overlaid contour lines. For example, in panel d, Site 806 is slightly cooler than $2^{\circ} \mathrm{C}$ in the modern ocean but was slightly warmer than $2^{\circ} \mathrm{C}$ during the mid-Piacenzian. Actual estimates at all sites are shown in Fig. 4 and given in Table 2.

\subsection{Enhanced mid-Piacenzian NADW}

The PRISM3D ocean reconstruction is characterized by enhanced paleo NADW extending further south than modern NADW. Several lines of evidence support this finding. The PRISM3 surface temperature anomaly (Figs. 5 and 7) highlights a large area of the subpolar North Atlantic that is warmer than modern. Preliminary climate modeling experiments with the GISS GCM (Dowsett et al. 2009; Chandler, unpublished data) suggest this same region experienced a decrease in precipitation minus evaporation (P-E) which might suggest production of NADW slightly warmer yet more dense due to increased evaporation in the region (Dowsett et al., 2009). Khélifi et al. (2009) suggest that an increase in Mediterranean Sea Outflow Water (MOW) possibly intensified NADW formation.

Oxygen and carbon isotope data as well as carbonate preservation evidence exists to suggest that prior to $3.0 \mathrm{Ma}$ the production of northern component deep water was higher than after 3.0 Ma or present day (Sarnthein and Fenner, 1988; Raymo et al., 1996; Wright and Miller, 1996; Poore et al., 2006).

Oppo and Fairbanks (1987) generated a mixing equation to estimate the \%overflow of NCW, the precursor to modern NADW, through time using the North Atlantic, Southern
Ocean and North Pacific as end members

$\mathrm{NCW}=\frac{\delta^{13} \mathrm{C}_{\mathrm{SO}}-\delta^{13} \mathrm{C}_{\mathrm{PO}}}{\delta^{13} \mathrm{C}_{\mathrm{NA}}-\delta^{13} \mathrm{C}_{\mathrm{PO}}} \times 100$

where $\delta^{13} \mathrm{C}_{\mathrm{SO}}, \delta^{13} \mathrm{C}_{\mathrm{PO}}$ and $\delta^{13} \mathrm{C}_{\mathrm{NA}}$ are $\delta^{13} \mathrm{C}$ estimates for the Southern Ocean, Pacific Ocean and North Atlantic, respectively. $\delta^{13} \mathrm{C}$ in this instance is used as a measure of nutrient content of deep water; North Atlantic surface water is depleted in nutrients and deep water gains nutrient content with age. While the interpretation of $\delta^{13} \mathrm{C}$ is more complicated, Wright and Miller (1996) and more recently (Poore et al., 2006) used $\delta^{13} \mathrm{C}$ to calculate an estimate of NCW (using Eq. 1). The results of both studies are relevant to our analysis of mid-Piacenzian deep ocean circulation. Longterm trends in \% NCW appear to be related to vertical movements of the Greenland-Scotland Ridge with high NCW production during the PRISM interval followed by a sharp decrease roughly corresponding to the initiation of Northern Hemisphere glaciation (Wright and Miller, 1996; Poore et al., 2006).

In a similar study, Raymo et al. (1996) used carbon and oxygen isotopes to suggest enhanced production of NCW and greater warmth during the mid-Piacenzian. While there are other factors that can affect the interpretation of $\delta^{13} \mathrm{C}$ records, these data appear to corroborate an increased warm $\mathrm{NCW}$ at the same time as warmer surface ocean conditions. 


\subsection{Restriction and displacement of antarctic waters}

Mid-Pliocene diatoms were analysed by Barron (1996a, b) from 24 Southern Ocean sites. Diatom-based SST estimates for the Southern Ocean were determined by estimating the position of the Antarctic Polar Front relative to the various sites (Dowsett et al., 1996). In general, the Polar Front Zone expanded during the mid-Piacenzian with the Sub-Antarctic Front essentially at its modern position; the mid-Piacenzian Antarctic Polar Front was shifted toward the south. This results in warmer surface conditions closer to the continent and supports a reduction of AABW production. The BWT data suggest warmer conditions and restriction to regions south of the equator.

Enhanced NADW (see Sect. 6.1) appears to have been accomplished in the vertical direction as well, and paleo AAIW which lies above NADW, was displaced slightly relative to its present day position, which may account for the small negative anomaly seen in the $1000 \mathrm{~m}-1300 \mathrm{~m}$ depth interval globally (see Fig. 4).

\subsection{Mid-Piacenzian thermocline and upwelling behavior}

The reconstruction of the upper ocean is based upon the downward propagation of the surface temperature anomaly. While we currently lack direct measurement of the depth of thermocline in the tropical Pacific, the PRISM3 surface reconstruction does include a reduced $\mathrm{E}-\mathrm{W}$ temperature gradient due to warmer than present day conditions in the eastern equatorial Pacific (Dowsett and Robinson, 2009). The downward propagation of this surface temperature anomaly by our methodology creates a first approximation of a deepening of the thermocline which is documented by Ravelo et al. (2006).

In mid-latitude upwelling regions of the Pacific Ocean, data exist suggesting warmer nutrient-rich upwelled-water (Dekens et al., 2007). While these data have not yet been incorporated in the PRISM3 SST reconstruction, they may suggest a warmer southern source subsurface water mass.

\subsection{Effect of a warmer global ocean on climate}

Surface ocean warming during the mid-Piacenzian may have resulted in lower surface density in the North Atlantic and therefore a slowdown in the thermohaline circulation (THC). Coupled ocean-atmosphere numerical modeling studies incorporating mid-Piacenzian surface conditions seemingly dispute this mechanism (Haywood and Valdes, 2004). However, coupled model experiments initiated with the Atlantic sector of the PRISM3D deep ocean temperature reconstruction showed that this addition created an increase in MOC (Chandler, unpublished data). This might be explained by increased surface evaporation in the region of present day NADW formation (Dowsett et al., 2009). A response to the poleward shift and intensification of winds in a warming climate has also been suggested (Toggweiler and Russell, 2008).

The documentation, however sparse, of both surface and deep ocean warming during the mid-Piacenzian is intriguing, especially in light of estimates of continued global warming through the end of this century (Jansen et al., 2007). Numerical models of Earth Climate System remain the best tool for understanding the role of a warmer ocean circulation system and for understanding the conditions that may result from such a phenomena.

\subsection{Possible causes of mid-Piacenzian warmth supported by PRISM3D}

For two decades the question of the cause of Pliocene warming has eluded investigators. The two most prominent explanations, increased atmospheric concentrations of $\mathrm{CO}_{2}$ and increased meridional ocean heat flux, are attractive. Both mechanisms have different signatures in the sedimentary record, and neither have been clearly detected. It is safe to say that both have had a prominent role on the magnitude of Pliocene warmth, but there are other mechanisms that should be tested using numerical models.

Tectonically forced changes in various ocean gateways played an important role in metering the circulation of water into different ocean basins. The work on the GreenlandScotland Ridge in the North Atlantic appears to have a significant effect on Neogene deep water production (Wright and Miller, 1996; Poore et al., 2006). Likewise, the depth of the Indonesian throughflow is an important aspect of the paleoceanographic circulation in the Pacific (Cane and Molnar, 2001; Karas et al., 2009). It has long been held that the depth of the Central American Seaway (CAS) has had a profound effect on Northern Hemisphere climate (Haug et al., 2001; Steph et al., 2006). While the impact of these gateways has been debated and assessed using numerical modeling, a careful evaluation of global bathymetry for the mid-Piacenzian would be a great benefit to future experiments in that it would allow for all gateways to interact as they did in the past, at the time we observe surface and deep ocean warming.

Finally, the role of tropical storms in moving heat from equator to poles may be underestimated in all but the most sensitive Earth System Models and may not have been adequately explored for mid-Piacenzian paleoclimate scenarios (Emanuel, 2001; Sriver and Huber, 2007).

Thus, the ocean temperature reconstruction presented here begs questions about the very nature and sensitivity of the climate system. New and innovative data sets representing past conditions (e.g. bathymetry) and processes (e.g. tropical storms) may hold the key to understanding the last great episode of global warmth and may therefore help navigate future climate conditions. 


\section{Conclusions}

Earth surface conditions during the mid-Piacenzian have been known for some time to be warmer than present day in the mid- and high latitudes. The resolution with which we can reconstruct those surface conditions is increasing as the tools and proxies of paleoclimatology evolve. The deep ocean is not as well known, yet is a fundamental component of the climate system and has become critical to our understanding of this last period of global warming similar in magnitude to what is expected for the end of this century.

Past deep ocean work concentrated on stable isotope analyses of deep-sea sequences through the mid-Piacenzian. These studies suggest an enhancement of Northern Component Water (NCW) relative to present day from sites in the North Atlantic, Southern Ocean and Pacific. We have utilized direct temperature estimates $(\mathrm{Mg} / \mathrm{Ca}$ paleothermometry utilizing Krithe) from mid-Piacenzian sequences that corroborate the concept of increased production of warmer NCW during this time interval. These temperature data fit well with mid-Piacenzian surface temperatures estimates as well as the few existing benthic foram based $\mathrm{Mg} / \mathrm{Ca} \mathrm{BWT}$ estimates from our time interval (Lear et al., 2000; Billups and Schrag, 2003; Khélifi et al., 2009)

In our opinion, all data point to the generation of warmer NADW, which expanded as a water mass and extended further south toward Antarctica. The polar front zone was expanded yet positioned closer to Antarctica at this time, and AAIW was formed although it was slightly warmer than at present. We speculate that AAIW and AABW did not extend as far north as they do today. This hypothetical model and these temperature data have been used to generate a three dimensional thermal reconstruction of the mid-Piacenzian global ocean which is being used to initiate coupled oceanatmosphere model experiments and in data-model validation work (Please see the PRISM web site for more information and links to data: http://geology.er.usgs.gov/eespteam/prism/ index.html). Future work must include analysis of the upper waters (depths $<1000 \mathrm{~m}$ ) including salinity estimates so that true water mass properties can be documented.

As the number of BWT sites increase, this 3-D reconstruction may be revised to reflect new data and more accurately portray mid-Piacenzian conditions.

Acknowledgements. We thank M. Williams and J. Groeneveld for their helpful comments and useful suggestions. This reconstruction would not have been possible without many conversations and discussions with T. Cronin, G. Dwyer, M. Chandler and A. Haywood. Special thanks to Danielle Stoll for help with figures and illustrations. Rocio Caballero and Karine Renaud helped with various aspects of data reduction. $\mathrm{Mg} / \mathrm{Ca}$ analyses were performed at Duke University; Alkenone analyses were performed at Brown University. This work was supported by the US Geological Survey Office of Global Change and is a product of the PRISM Project.

Edited by: G. Lohmann

\section{References}

Barron, J. A.: Diatom constraints on the position of the Antarctic Polar Front in the middle part of the Pliocene, Mar. Micropaleontol., 27, 195-213, 1996a.

Barron, J. A.: Diatom constraints on sea surface temperatures and sea ice distribution during the middle part of the Pliocene, US Geol. Surv., Open File Rep., 96-713, 45 pp., 1996 b.

Berggren, W. A.: The Pliocene time scale: calibration of planktonic foraminiferal and calcareous nannoplankton zones, Nature, 243, 391-397, 1973.

Berggren, W. A.: Late Neogene planktonic foraminiferal biostratigraphy of the Rio Grande Rise (South Atlantic), Mar. Micropaleontol., 2, 265-313, 1977.

Berggren, W. A., Kent, D. V., Swisher, C. C., and Aubry, M. P.: A revised Cenozoic geochronology and chronostratigraphy, in: Geochronology, time scales and global stratigraphic correlation, edited by: Berggren, W. A., Kent, D. V., Aubry, M. P., and Hardenbol, J., Tulsa, Society for Sedimentary Geology Special Publication, 129-212, 1995.

Billups, K. and Schrag, D. P.: Application of benthic foraminiferal $\mathrm{mg} / \mathrm{ca}$ ratios to questions of cenozoic climate change, Earth Planet. Sc. Lett., 209, 181-195, 10.1016/S0012-821X(03)000670, 2003.

Bukry, D.: Low-latitude coccolith biostratigraphic zonation, Initial Rep. Deep Sea, 15, 685-703, 1973.

Bukry, D.: Coccolith and silicoflagellate Stratigraphy, Northwestern Pacific Ocean, Deep Sea Drilling Project Leg 32, Initial Rep. Deep Sea, 32, 677-701, 1975.

Brierley, C. M., Fedorov, A. V., Zhonghui L., Herbert, T. D., Lawrence, K. T., and LaRiviere, J. P.: Greatly expanded tropical warm pool and weakened Hadley Circulation in the early Pliocene, Science, 323(5922), 1714-1718, 2009.

Cane, M. and Molnar, P.: Closing of the Indonesian seaway as a precursor to east African aridification around 3-4 million years ago, Nature, 411, 157-162, 2001.

Chandler, M., Dowsett, H., and Haywood, A.: The PRISM model-data cooperative: mid-Pliocene data-model comparisons, PAGES News, 16, 24-25, 2008.

Cronin, T. M., Dowsett, H. J., Dwyer, G. S., Baker P. A., and Chandler, M.: Mid Pliocene deep-sea bottom water temperatures based on ostracode Mg/Ca ratios, Mar. Micropaleontol., 54, 249261, 2005.

Dekens, P. S., Ravelo, A. C., and McCarthy, M. D.: Warm upwelling regions in the Pliocene warm period, Paleoceanography, 22, PA3211, doi:10.1029/2006PA001394, 2007.

Dowsett, H. J.: The PRISM palaeoclimate reconstruction and Pliocene sea-surface temperature, in: Deep-time perspectives on climate change: marrying the signal from computer models and biological proxies, edited by: Williams, M., Haywood, A. M., Gregory, J. and Schmidt, D., The Micropalaeontological Society 
Special Publications, The Geological Society of London, 459480, 2007.

Dowsett, H., Barron, J., and Poore, R.: Middle Pliocene sea surface temperatures: a global reconstruction, Mar. Micropaleontol., 27, 13-25, 1996.

Dowsett, H. J., Barron, J. A., Poore, R. Z., Thompson, R. S., Cronin, T. M., Ishman, S. E., and Willard, D. A.: Middle Pliocene paleoenvironmental reconstruction: PRISM2, US Geol. Surv., Open File Rep., 99-535, 1999.

Dowsett, H. J., Chandler, M. A., Cronin, T. M. and Dwyer, G. S.: Middle Pliocene sea surface temperature variability, Paleoceanography, 20, PA2014, doi:10.1029/2005PA001133, 2005.

Dowsett, H. J., Chandler, M. A., and Robinson, M. M.: Surface temperatures of the mid-Pliocene North Atlantic Ocean: implications for future climate, Philos. T. R. Soc. A, 367, 69-84, 2009.

Dowsett, H. J., Cronin, T. M., Poore, R. Z., Thompson, R. S., Whatley, R. C., and Wood, A. M.: Micropaleontological evidence for increased meridional heat transport in the North Atlantic Ocean during the Pliocene, Science, 258, 1133-1135, 1992.

Dowsett, H. J. and Poore, R. Z.: A new planktic foraminifer transfer function for estimating Pliocene-Holocene paleoceanographic conditions in the North Atlantic, Mar. Micropaleontol., 16, 1-23, 1990.

Dowsett, H. J. and Robinson, M. M.: Stratigraphic framework for Pliocene palaeoclimate reconstruction: the correlation conundrum, Stratigraphy, 3, 53-64, 2006.

Dowsett, H. J. and Robinson, M. M.: Mid-Pliocene equatorial Pacific sea surface temperature reconstruction: a multi-proxy perspective, Philos. T. R. Soc. A, 367, 109-126, 2009.

Dowsett, H. J., Robinson, M. M., Dwyer, G. S., Chandler, M. A., and Cronin, T. M.: PRISM3 DOT1 Atlantic basin reconstruction, US Geol. Surv., Data Series, US Geological Survey Data Series 189, available at: http://pubs.usgs.gov/ds/2006/189/, 2006.

Dowsett, H., Thompson, R., Barron, J., Cronin, T., Fleming, F., Ishman, S., Poore, R., Willard, D., and Holtz, T.: Joint investigations of the Middle Pliocene climate I: PRISM paleoenvironmental reconstructions, Global Planet. Change, 9, 169-195, 1994.

Dwyer, G. S.: DSDP 592 and ODP 754, 804, 805, 806, 928, 929, 982, 1085, 1090, 1092, 1123, 1236, 1237, 1239 and 1241 ostracode $\mathrm{Mg} / \mathrm{Ca}$ data, IGBP PAGES/World Data Center for Paleoclimatology, Data Contribution Series \# 2009-011, NOAA/NCDC Paleoclimatology Program, Boulder CO, USA, 2009.

Dwyer, G. S. and Chandler, M. A.: Mid-Pliocene sea level and continental ice volume based on coupled benthic $\mathrm{Mg} / \mathrm{Ca}$ palaeotemperatures and oxygen isotopes, Philos. T. R. Soc. A, 367, 157$168,2009$.

Emanuel, K.: Contribution of tropical cyclones to meridional heat transport by the oceans, J. Geophys. Res., 106(D14), 1477114781, 2001.

Gradstein, F., Ogg, J., and Smith A.: A geologic time scale 2004, Cambridge, UK, Cambridge University Press, 589 pp., 2004.

Haug, G. H., Tiedemann, R., Zahn, R., and Ravelo, A. C.: Role of panama uplift on oceanic freshwater balance, Geology, 29, 207210, 2001.

Haywood, A. M. and Valdes, P. J.: Modelling Pliocene warmth: contribution of atmosphere, oceans and cryosphere, Earth Planet. Sc. Lett., 218, 363-377, 2004.

Hodell, D. A. and Ciesielski, P. F.: Stable isotopic and carbonate stratigraphy of the Plio-Pleistocene of the Ocean Drilling Pro- gram (ODP) Hole 704A: Eastern sub-Antarctic South Atlantic, Proceedings of the Ocean Drilling Program, Scientific Results, 114, 409-436, 1991.

Jansen, E., Overpeck, J., Briffa, K. R., Duplessy, J. C., Joos, F., Masson-Delmotte, V., Olago, D., Otto-Bliesner, B., Peltier, W. R., Rahmstorf, S., Ramesh, R., Raynaud, D., Rind, D., Solomina, O., Villabla, R., and Zhang, D.: Palaeoclimate, in: Climate Change 2007: The Physical Science Basis. Contribution of Working Group I to the Fourth Assessment Report of the Intergovernmental Panel on Climate Change, edited by: Solomon, S., Qin, D., Manning, M., Chen, Z., Marquis, M., Averyt, K. B., Tignor, M., and Miller, H. L., Cambridge University Press, Cambridge, UK, 1-21, 2007.

Karas, C., Nurnberg, D., Gupta, A. K., Tiedemann, R., Mohan, K., and Bickert, T.: Mid-Pliocene climate change amplified by a switch in Indonesian subsurface throughflow, Nat. Geosci., 2, 434-438, 2009.

Khélifi, N., Sarnthein, M., Andersen, N., Blanz, T., Frank, M., Garbe-Schönberg, D., Haley, B., Stumpf, R., and Weinelt, M.: A major and long tem Pliocene intensification of the Mediterranean outflow, 3.5-3.0 Ma ago, 37(9), 811-814, 2009.

Lear, C. H., Elderfield, H., and Wilson, P. A.: Cenozoic deepsea temperatures and global ice volumes from $\mathrm{mg} / \mathrm{ca}$ in benthic foraminiferal calcite, Science, 287, 269-272, 2000.

Levitus, S. and Boyer, T. P.: World ocean atlas 1994 (4): Temperature, NOAA Atlas NESDIS, 4, Washington, DC, US Department of Commerce, 1994.

Lisiecki, L. E. and Raymo, M. E.: A Pliocene-Pleistocene stack of 57 globally distributed benthic $\mathrm{d}^{18} \mathrm{O}$ records, Paleoceanography, 20, PA1003, doi:10.1029/2004PA001071, 2005.

Martini, E.: Standard Tertiary and Quaternary calcareous nannoplankton zonation, in: Proc. II Int. Plankt. Conf., Roma, 1970, edited by: Ferinacci, A., Tecnoscienza, 2, 739-785, 1971.

Middleton, G. V.: Data analysis in the Earth Sciences using MATLAB, Prentice Hall, Upper Saddle River, New Jersey, 260 pp., 2000.

Oppo, D. W. and Fairbanks, R. G.: Variability in the deep and intermediate water circulation of the Atlantic Ocean during the past 25000 years: Northern Hemisphere modulation of the Southern Ocean, Earth Planet. Sc. Lett. 86, 1-15, 1987.

Poore, H. R., Samworth, R., White, N. J., Jones, S. M. and McCave, I. N.: Neogene overflow of Northern Component Water at the Greenland-Scotland Ridge, Geochem. Geophy. Geosy., 7, Q06010, doi:06010.01029/02005gc001085, 2006.

Ravelo, A. C., Dekens, P. S., and McCarthy, M.: Evidence for El Nino - like conditions during the Pliocene, GSA Today, 16, 4$11,2006$.

Raymo, M. E., Grant, B., Horrowitz, M., and Rau, G. H.: MidPliocene warmth: stronger greenhouse and stronger conveyor, Mar. Micropaleontol., 27, 313-326, 1996.

Raymo, M. E., Ruddiman, W. F., Backman, J., Clement, B. M. and Martinson, D. G.: Late Pliocene variation in Northern Hemisphere ice sheets and North Atlantic deep water circulation, Paleoceanography, 4, 413-446, 1989.

Reynolds, R. W. and Smith, T. M.: A high-resolution global sea surface temperature climatology, J. Climate, 8, 1571-1583, 1995.

Robinson, M. M.: New quantitative evidence of extreme warmth in the Pliocene arctic, Stratigraphy, 6(4), 1-10, 2009.

Robinson, M. M., Dowsett, H. J., and Chandler, M. A.: Pliocene 
role in assessing future climate impacts, EOS, 89, 501-502, 2008a.

Robinson, M. M., Dowsett, H. J., Dwyer, G. S. and Lawrence, K. T.: Reevaluation of mid-Pliocene North Atlantic sea surface temperatures, Paleoceanography, 23, PA3213, doi:10.1029/2008PA001608, 2008b.

Salzmann, U., Haywood, A. M., Lunt, D. J., Valdes, P. J., and Hill, D. J.: A new global biome reconstruction and data-model comparison for the Middle Pliocene, Global Ecol. Biogeogr., 17, 432-447, 2008.

Sancetta, C. and Silvestri, S.: High-resolution biostratigraphic and oceanographic events in the late Pliocene and Pleistocene North Pacific Ocean, Paleoceanography, 1, 163-180, 1986.

Sarnthein, M. and Fenner, J.: Global wind-induced change of deepsea sediment budgets, new ocean production and $\mathrm{CO}_{2}$ reservoirs ca. 3.3-2.35 Ma, Philo. T. R. Soc. B, 318, 487-504, 1988.

Shackleton, N. J., Hall, M. A., and Pate, D.: Pliocene stable isotope stratigraphy of Site 846, edited by: Pisias, N. G., Mayer, L. A., Janecsek, T. R., et al., Proceedings of the Ocean Drilling Program, Scientific Results, 138, 337-355, 1995.
Sohl, L. E., Chandler, M. A., Schmunk, R. B., Mankoff, K., Jonas, J. A., Foley, K. M., and Dowsett, H. J.: PRISM3/GISS topographic reconstruction, US Geol. Surv., Data Series, 419, 6 pp., 2009.

Sriver, R. L. and Huber, M.: Observational evidence for an ocean heat pump induced by tropical cyclones, Nature, 447, 577-580, 2007.

Steph, S., Tiedemann, R., Prange, M., Groeneveld, J., Nurnberg, D., Reuning, L., Schulz, M., and Haug, G. H.: Changes in caribbean surface hydrography during the pliocene shoaling of the central american seaway, Paleoceanography, 21, PA4221, doi:10.1029/2004PA001092, 2006.

Tiedemann, R., Sarnthein, M., and Shackleton, N.: Astronomical timescale for Pliocene Atlantic $\mathrm{d}^{18} \mathrm{O}$ and dust flux records of Ocean Drilling Program Site 659, Paleoceanography, 9, 619638, 1994.

Toggweiler, J. R. and Russell, J.: Ocean circulation in a warming climate, Nature, 451, 286-288, 2008.

Wright, J. D. and Miller, K. G.: Control of North Atlantic Deep Water circulation by the Greenland-Scotland Ridge, Paleoceanography, 11, 157-170, 1996. 